\title{
Networking of Strategic Partnerships in Higher Education: Prerequisites and Readiness of Universities
}

\section{Establecimiento de redes de asociaciones estratégicas en la educación superior: prerrequisitos y preparación de las universidades}

\author{
Olga A. Baturina \\ Vladivostok State University of Economics and Service, Vladivostok, Rusia \\ ORCID: https://orcid.org/0000-0001-9357-3307 \\ Tatyana V. Terentyeva \\ Vladivostok State University of Economics and Service, Vladivostok, Rusia \\ ORCID: https://orcid.org/0000-0001-5767-6720
}

Recibido 16-12-19 Revisado 17-01-20 Aprobado 15-03-20 En línea 16-03-20

Correspondencia

Email: olga.ruban@vvsu.ru
Citar como:

Baturina, O. A., \& Terentyeva, T. V. (2020). Networking of Strategic Partnerships in Higher Education: Prerequisites and Readiness of Universities. Propósitos y Representaciones, 8(3). doi: http://dx.doi.org/10.20511/pyr2020.v8n3.481

(c) Universidad San Ignacio de Loyola, Vicerrectorado de Investigación, 2020.

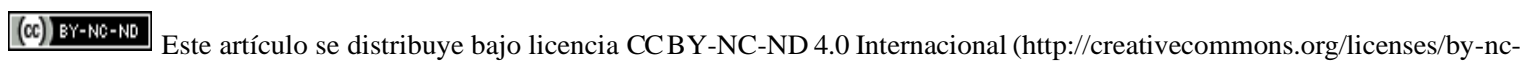
$\mathrm{nd} / 4.0 /)$. 


\section{Summary}

The priority task of the modern education system development is the organization of a comprehensive partnership, which, among other things, implies the development of network interactions between the university and various economic entities. In this regard, the need to apply new forms of partnerships is actualized, in which openness and readiness of partners for equal, effective and multilateral interaction is in the first place. However, at present, not all economic entities are ready to implement such a form of partner relations. The article examines the tendency of networking in higher education and the level of their development from the perspective of openness. In this work, we tested the methodology for a university readiness evaluation to form and develop a strategic partnership based on the network approach using the example of leading universities of the Russian Federation.

Keywords: Networking; Network Readiness; Strategic Partnership; Methodology; Education; University; Federal Universities; Interorganizational Interactions; The Principle of Openness.

\section{Resumen}

La tarea prioritaria del desarrollo del sistema educativo moderno es la organización de una asociación integral, que, entre otras cosas, implica el desarrollo de interacciones de red entre la universidad y varias entidades económicas. En este sentido, se actualiza la necesidad de aplicar nuevas formas de asociación, en las que la apertura y la disposición de los socios para una interacción igual, efectiva y multilateral es, en primer lugar. Sin embargo, en la actualidad, no todas las entidades económicas están listas para implementar tal forma de relaciones con los socios. El artículo examina la tendencia de las redes en la educación superior y el nivel de su desarrollo desde la perspectiva de la apertura. En este trabajo, probamos la metodología para una evaluación de preparación universitaria para formar y desarrollar una asociación estratégica basada en el enfoque de red utilizando el ejemplo de las principales universidades de la Federación de Rusia.

Palabras clave: Redes; Preparación de redes; Asociación estratégica; Metodología; Educación; Universidad; Universidades federales; Interacciones interorganizacionales; El principio de apertura.

\section{Introduction}

The development of modern society, a high degree of informatization led to the development of network forms of interaction in the field of education, in particular, the federal law "On education in the Russian Federation" (273- $\$ 3$ dated on December 29, 2012) the network form of education was recorded. Thus, the importance of partnerships between educational institutions with various organizations is increased to ensure their own competitiveness. The ongoing changes require universities to ensure maximum openness of university activities. Moreover, openness is understood not only as access provision to educational programs, but in a broad sense: information, communication, transparency of management procedures, strategic goals, etc. The analysis of strategy development at federal and most national research universities showed that one of the main landmarks in their development is the formation and the development of strategic partnership. However, at the present stage, interactions are developed mainly between various educational organizations and less frequently between universities and business structures.

Proceeding from the performed analysis of scientific literature, the most common forms of interorganizational relationships are the network, cluster, and strategic alliance. So cluster is 
the variety of network form of integration, the purpose of which is to perform a specific function. A distinctive feature is the spontaneous nature of education, which is explained by the nature of self-organization, the lack of the need to set a common goal and objectives. Informal interactions and connections dominate as an organizational basis. This feature distinguishes the cluster form of relations from the network one significantly.

The strategic alliance as the form of integration has a more rigid structure and a high degree of relation formalization. It is created to achieve common mutually beneficial goals. The similarity with networks is represented by the need to agree goals. However, the risk of such a partnership is the possibility of losing individual strategic autonomy. Alliances are characterized by the contractual basis of relations, which makes it difficult to enter and exit from it. Participation in other associations is undesirable for the alliance members, unlike networks.

Interorganizational networks have a self-governing structure, cover a wider category of entities, and, unlike clusters, assume the existence of agreed goals and objectives among the participants (Stryabkova, 2015). The institutional basis is contractual and informal relationships and connections. Unlike alliance partners have a high degree of freedom. The advantage of the strategic network over other forms of integration is the joint use of partner resources, which increases the business abilities, the resources of the participating organizations and contributes to the achievement of collective efficiency of the activity. The main difference between networks and strategic alliances is "a higher level of trust", and many authors also note the possibility of simultaneous participation in several networks (Botnaryuk \& Semerkova, 2011).

Later, we will consider the network as a set of strategic network partnerships in this study. The identified characteristics made it possible to establish that the networks are a self-managing flexible system with stable multiple connections between an unlimited number of participants. They are based on a high level of trust and are aimed at agreed goals and objective achievement.

In the field of education, we can distinguish the development of network relations that are realized through horizontal links. The beginning of this is most often correlated with the ideas of the Bologna process, which is aimed at a single European educational space development.

J. Love and E. Wenger, examining the concept of knowledge-sharing communities, use the term "Communities of Practice" for the first time, which, according to literature, means "the groups of people who have common interests and goals and move toward these goals through close interaction. The process is based on close network direct interaction and mutual exchange" (Wenger, 1999).

So Zubarev A.E., Ryabchenko S.A. consider Russian and foreign experience of network partnership implementation in the field of education. They note that "... on the basis of a contract (agreement) on network cooperation, universities in different countries have the opportunity to become the participants in one or several network associations" (Zubarev \& Ryabchenko, 2016).

Under the influence of the knowledge economy development, network forms cover various areas of activity. L. Advisson considers strategic network structures as the organizational forms that attempt to realize competitive advantages through cooperation between legally independent but economically dependent subdivisions (Advison, 2005). The additional value of the network is in relationships beyond obvious exchanges.

Ryuegg - Sturum I., Young M. define network interactions as the ability to belong to several systems (Ryuegg-Shturm \& Young, 2001). According to V. Chekmarev, this type of affiliation is the condition for the considerable economic space with its cellular network structure 
(Chekmarev, 2002). The development of such interactions is possible only on the basis of trust and ability to cooperate.

Trust in the network approach is considered as the factor in the strategic stage of building partnerships, their maintenance and development. Palmer A. notes that the partnership is realized by the staff of the partners and the development of personal interactions creates mutual trust (Palmer, 1996).

M. Castells defines networks as "a set of interconnected nodes, the specific content of each of which depends on the nature of a particular network structure" (Castells \& Blackwell, 1998). A distinctive feature of network interactions is the presence of core competencies among participants, the combination of which allows you to build chains quickly and get a synergistic effect by sharing different types of resources.

Bourdieu P. notes that the advantage of constant participation in the network interaction is free access to available resources. This forms trust within the network (Bourdieu, 2005).

The factors of competitive advantage development as the result of network interactions are assets, knowledge sharing, complimentary resources and the abilities of participants (actors). It should be noted that many authors call social capital as the factor shaping the value of network interactions, which is of particular importance during a network approach consideration to the development of strategic partnership with a university.

The network approach to educational management has also found a reflection. Some authors single out "relational assets" as the competitive advantages of educational institutions, which provide "access to the best resources and lie in relationships with numerous stakeholders (stakeholder groups) (Gresko et al., 2012).

Mindelly L.E., and Pipia L.K. consider the development of network structures in the knowledge economy, highlighting the special role of universities in the production, reproduction and transformation of knowledge (Mindeli \& Pipiya, (2007). Isaev S.N., Tikhomirovova N.V. consider the practice of educational network development and introduce the concept of a distributed educational network, which is based on interactions, geographically separated students and teachers, partners, jointly performing the learning process (Isaev \& Tikhomirova, 2011).

Thus, the network approach is actively used in various fields of knowledge, but partnerships between universities or between universities and enterprises for the implementation of educational services are most often considered in the field of education. The development of an open (network) university model within the framework of new state management concept development reveals, first of all, the need to build strategic partnerships with various groups of participants, and secondly, the conceptual change of their formation and development principles (Varkulevich et al., 2018; Lazarev et al., 2018; Petruk, 2018; Nedoluzhko et al., 2019). Under these conditions, universities need to look for new forms of relation development with the external environment in order to fill the lack of resources and improve their performance and competitiveness in the long term. The development of a strategic partnership based on a network approach is considered by the authors as one of the effective ways for this problem solution. However, it is necessary to understand how the current state of partnership interactions meets the principle of openness, which is one of the most significant in the network paradigm. 


\section{Methodo}

The purpose of the network readiness assessment is to establish the current level of university strategic partnership development from the perspective of their possible development based on the network approach.

In the author's methodology, they proposed the adaptation of the network readiness index to assess the potential of a university concerning strategic partnership development in the context of a network approach. The Network Readiness Index is usually used as the tool for monitoring the development of a network economy, participates in comparative rating development characterizing its level of development.

The following structural elements of the indicator are used:

- informational openness, as the characteristic of the university partner environment, reflecting the university ability to develop in the context of the network approach implementation;

- the involvement of partners in the university activities, which characterizes the willingness of partners to use various forms of interaction;

- the stage of university strategic partnership development, as the component of evaluating the use of network technologies during the implementation of partnership interactions.

Rating technology involves the consistent summation of each criterion scores. The score for each criterion is set according to the following principle:

- availability of characteristics on university website - 1 point;

- the lack of characteristics on university website - 0 points.

In order to evaluate each structural element in the methodology, a number of criteria and indicators are provided, the conformity of which is presented in Table 1. 
Table 1.

Indicators of University Network Readiness Assessment

\begin{tabular}{|c|c|c|}
\hline $\begin{array}{l}\text { NI evaluation } \\
\text { type }\end{array}$ & Evaluation object & Evaluation criteria \\
\hline \multirow[t]{5}{*}{$\begin{array}{l}\text { Informational } \\
\text { openness }\end{array}$} & \multirow{2}{*}{$\begin{array}{l}\text { Availability (openness) of } \\
\text { information about NI on the } \\
\text { university website. }\end{array}$} & $\begin{array}{l}\text { Availability of partnership information on } \\
\text { the main site. }\end{array}$ \\
\hline & & $\begin{array}{l}\text { Availability of information about } \\
\text { partnerships on the website of departments } \\
\text { / institutes / divisions. }\end{array}$ \\
\hline & $\begin{array}{l}\text { Availability of information } \\
\text { about strategic partners on the } \\
\text { university website. }\end{array}$ & $\begin{array}{l}\text { The presence of the partner description on } \\
\text { the site / the links to the official website of } \\
\text { the partner. }\end{array}$ \\
\hline & $\begin{array}{l}\text { Availability of information } \\
\text { about the results of partnerships } \\
\text { on the university website. }\end{array}$ & $\begin{array}{l}\text { The availability of site information on the } \\
\text { results of partnerships. }\end{array}$ \\
\hline & Rating & $\max =4$ \\
\hline \multirow{5}{*}{$\begin{array}{l}\text { The } \\
\text { involvement } \\
\text { of partners in } \\
\text { university } \\
\text { activities }\end{array}$} & \multirow{4}{*}{$\begin{array}{l}\text { The degree of strategic partner } \\
\text { participation in the activities of } \\
\text { some university (by main } \\
\text { areas). }\end{array}$} & $\begin{array}{l}\text { The presence of partnerships in the field of } \\
\text { education. }\end{array}$ \\
\hline & & $\begin{array}{l}\text { The presence of partnerships in the } \\
\text { research field. }\end{array}$ \\
\hline & & $\begin{array}{l}\text { The presence of partnerships in the field of } \\
\text { innovation. }\end{array}$ \\
\hline & & $\begin{array}{l}\text { The presence of partnerships in the social } \\
\text { sphere. }\end{array}$ \\
\hline & Rating & $\max =4$ \\
\hline \multirow{5}{*}{$\begin{array}{l}\text { NI } \\
\text { development } \\
\text { level } \\
\text { evaluation at } \\
\text { universities }\end{array}$} & \multirow{2}{*}{$\begin{array}{l}\text { The degree } \\
\begin{array}{l}\text { institutionalization } \\
\text { in of the } \\
\text { university }\end{array} \text { strategic } \\
\text { partnerships. }\end{array}$} & $\begin{array}{l}\text { Availability of endowment funds / alumni } \\
\text { associations / professional associations. }\end{array}$ \\
\hline & & $\begin{array}{l}\text { The presence of the institute / NI } \\
\text { department at the University. }\end{array}$ \\
\hline & \multirow[t]{2}{*}{$\begin{array}{l}\text { The manifestation of network } \\
\text { forms of partnership. }\end{array}$} & $\begin{array}{l}\text { University participation in university } \\
\text { consortiums/associations. }\end{array}$ \\
\hline & & $\begin{array}{l}\text { University participation in online training } \\
\text { programs. }\end{array}$ \\
\hline & Rating & $\max =4$ \\
\hline
\end{tabular}

The total rating of the strategic partnership development at a university max $=12$

The value of the university network readiness indicator allows to determine the university compliance with the key criteria of the network approach, as well as the points of effort application for the development of strategic partnerships on its basis. The definition of university network readiness is based on the use of the rating method using the content analysis of university websites.

Evaluation of these three criteria in the vertical allows us to obtain a consolidated assessment of university strategic partnership development and to determine the future vector of 
development on its basis. If you carry out an assessment horizontally, then you can evaluate each of the three specified elements by the totality of universities.

The use of the grouping method in this assessment methodology makes it possible to determine the degree of university readiness for networking and, in general, the development of strategic partnership across university groups, as well as in the context of estimated parameters.

\section{Results}

The testing of the proposed methodology was carried out at the leading federal universities of the Russian Federation. This study assesses the strategic partnerships of universities by criteria and within the group.

Top 100 universities of the Russian Federation were selected according to the National University Rating, as well as the Crimean federal university named after V.I. Vernadsky, which was included in the sample for assessing the level of strategic partnership development of the full group "Federal Universities".

Among the federal districts of the Russian Federation, the Central Federal District is the undisputed leader in the number of universities, in which about $37 \%$ of the sample is concentrated. These are 37 universities, 29 of them are located in Moscow. The Far Eastern and North Caucasus federal districts are represented weakest in the sample - 3 universities each, of which 2 and 1 are federal, respectively. There are no national research and reference data in these subjects.

According to the results of the assessment, the average rating of the strategic partnership informational openness among the leading universities of the Russian Federation is 2 (max - 6). Based on the obtained value, we can conclude that universities have a very low level of readiness for networking, one of the basic principles of which is activity openness.

The analysis of the criteria for information openness evaluation among universities allowed to identify general trends in reflecting information about strategic partners on websites:

- the majority of universities $(61 \%)$ do not reflect information on the main site, but on structural units, of which $23 \%$ share the strategic partners of the university and its structural units;

- the information about interaction results is almost secret. Three out of 100 analyzed universities place reports on strategic partnership results;

- 9 out of 100 universities posted concluded agreements on strategic partnership.

The average rating of involvement of partners in the activities of the university is at a satisfactory level, with the exception of such interaction sphere as innovative - 2 (max - 4).

The greatest degree of partner involvement in educational activities (89\%) is the organization of student practices and exchange programs with foreign universities. Much less common are joint educational programs with Russian universities. The partnership relations in the sphere of innovations were noted only in 22 out of 101 universities.

The average rating of the strategic partnership development stage among leading universities is 1 ( $\max -6)$. Based on the analysis, we can note the extremely low level of institutionalization of the strategic partnership - 9\% of universities have a specialized department and or coordination council in their organizational structure. Network forms of education are used by $3 \%$ of universities included in the sample. The highest values have the criteria associated with the participation of universities in consortia, associations - 20\%. About 35\% of universities use such forms of strategic partnership as endowment - foundations, graduate associations. 
The average overall assessment of the strategic partnership development at the leading universities of the Russian Federation is 5 out of 16 possible, which indicates a weak readiness of universities to networking.

Further, they performed the assessment of strategic partnership development for a group of federal universities. The results of the calculations are presented in table 2.

Table 2.

The level of the network strategic partnership development in the Federal University group

\begin{tabular}{|c|c|c|c|c|c|c|c|c|c|c|c|c|c|}
\hline 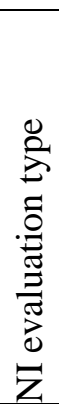 & $\begin{array}{l}\text { Evaluatio } \\
\text { n object }\end{array}$ & $\begin{array}{l}\text { Evaluation } \\
\text { ctiteria }\end{array}$ & 它 & 宣 & $\frac{P}{\Omega}$ & 它 & 空 & 豆 & ? & 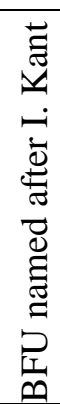 & 至 & 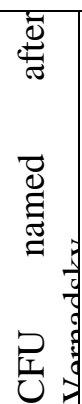 & 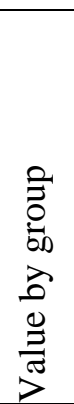 \\
\hline \multirow{6}{*}{ 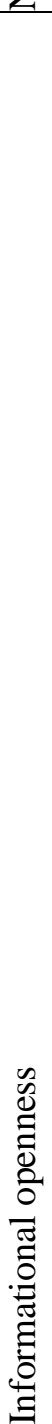 } & \multirow{2}{*}{$\begin{array}{l}\text { Availabilit } \\
\text { y } \\
\text { (openness } \\
\text { ) of } \\
\text { informatio } \\
\text { n about NI } \\
\text { on the } \\
\text { university } \\
\text { website }\end{array}$} & $\begin{array}{ll}\text { Availability } & \text { of } \\
\text { information } & \text { on } \\
\text { the main site. }\end{array}$ & & 1 & 1 & & & & 1 & & & & \\
\hline & & $\begin{array}{lr}\text { Availability } & \text { of } \\
\text { information } & \text { on } \\
\text { the website } & \text { of } \\
\text { departments } & \text { / } \\
\text { institutes } & \text { / } \\
\text { divisions. } & \end{array}$ & 1 & 1 & 1 & 1 & 1 & 1 & & 1 & & & \\
\hline & $\begin{array}{l}\text { Availabilit } \\
y \text { of } \\
\text { informatio } \\
n \text { about } \\
\text { strategic } \\
\text { partners } \\
\text { on the } \\
\text { university } \\
\text { website }\end{array}$ & $\begin{array}{l}\text { The presence of } \\
\text { the partner / links } \\
\text { description about } \\
\text { the official } \\
\text { partner website. }\end{array}$ & & 1 & 1 & 1 & 1 & & 1 & 1 & & & \\
\hline & \multirow{2}{*}{$\begin{array}{l}\text { Availabilit } \\
\mathrm{y} \text { of } \\
\text { informatio } \\
\mathrm{n} \text { about } \\
\text { the results } \\
\text { of } \\
\text { partnershi } \\
\text { ps on the } \\
\text { university } \\
\text { website }\end{array}$} & $\begin{array}{l}\text { Availability of } \\
\text { information about } \\
\text { the results of } \\
\text { partnerships on } \\
\text { the site. }\end{array}$ & & 1 & & & & & & & & & \\
\hline & & $\begin{array}{l}\text { Availability of } \\
\text { reports about NI } \\
\text { implementation } \\
\text { on the site. }\end{array}$ & & & & & & & & & & & \\
\hline & $\begin{array}{l}\text { Placement } \\
\text { of NI } \\
\text { agreement } \\
\text { on the }\end{array}$ & $\begin{array}{l}\text { Availability of } \\
\text { concluded } \\
\text { agreements on NI. }\end{array}$ & & & 1 & & & & & 1 & & & \\
\hline
\end{tabular}




\begin{tabular}{|c|c|c|c|c|c|c|c|c|c|c|c|c|c|}
\hline 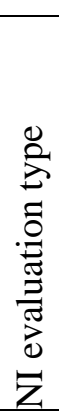 & $\begin{array}{l}\text { Evaluatio } \\
\text { n object }\end{array}$ & $\begin{array}{l}\text { Evaluation } \\
\text { ctiteria }\end{array}$ & 它 & 胥 & $\stackrel{\vec{I}}{\Omega}$ & $\stackrel{\vec{L}}{\Omega}$ & 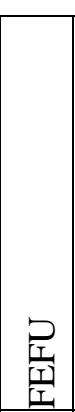 & $\begin{array}{r}\stackrel{2}{L} \\
\mathbf{Z} \\
\end{array}$ & $\begin{array}{l}? \\
\text { Z } \\
Z\end{array}$ & 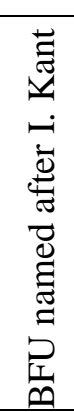 & 焉 & 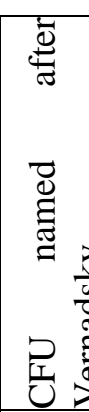 & 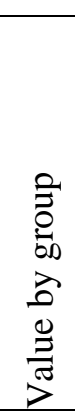 \\
\hline & $\begin{array}{l}\text { university } \\
\text { website. }\end{array}$ & & & & & & & & & & & & \\
\hline & Rating & $\max =6$ & 1 & 4 & 4 & 2 & 2 & 1 & 2 & 3 & 0 & 0 & 2 \\
\hline 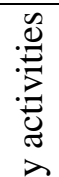 & $\begin{array}{l}\text { The } \\
\text { degree of }\end{array}$ & $\begin{array}{l}\text { The presence of } \\
\text { partnerships in } \\
\text { the field of } \\
\text { education. }\end{array}$ & 1 & 1 & 1 & 1 & 1 & 1 & 1 & 1 & 1 & & \\
\hline 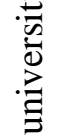 & $\begin{array}{l}\text { strategic } \\
\text { partner } \\
\text { participati }\end{array}$ & $\begin{array}{l}\text { The presence of } \\
\text { partnerships in } \\
\text { the research field. }\end{array}$ & & 1 & 1 & 1 & 1 & & 1 & & 1 & & \\
\hline 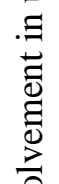 & $\begin{array}{l}\text { on in the } \\
\text { activities } \\
\text { of a a } \\
\text { university }\end{array}$ & $\begin{array}{l}\text { The presence of } \\
\text { partnerships in } \\
\text { the field of } \\
\text { innovation. }\end{array}$ & & 1 & & 1 & & & & & & & \\
\hline$\sum_{\Xi}^{0}$ & $\begin{array}{l}\text { (by main } \\
\text { areas) }\end{array}$ & $\begin{array}{l}\text { The presence of } \\
\text { partnerships in } \\
\text { the social sphere. }\end{array}$ & 1 & & 1 & & 1 & 1 & 1 & 1 & & & \\
\hline تَّة & Rating & $\max =4$ & 2 & 3 & 3 & 3 & 3 & 2 & 3 & 2 & 2 & 0 & 2 \\
\hline \multirow{6}{*}{ 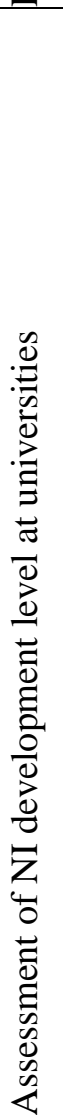 } & \multirow{4}{*}{$\begin{array}{l}\text { The } \\
\text { degree of } \\
\text { University } \\
\text { NI } \\
\text { institution } \\
\text { alization. }\end{array}$} & $\begin{array}{l}\text { The presence of } \\
\text { NI institute / } \\
\text { department at the } \\
\text { University. }\end{array}$ & & 1 & 1 & & & & & & & & \\
\hline & & $\begin{array}{l}\text { The presence of } \\
\text { the coordination } \\
\text { council / NI } \\
\text { center at the } \\
\text { University. }\end{array}$ & & & & & & & & & & & \\
\hline & & $\begin{array}{l}\text { Availability of } \\
\text { endowment funds } \\
/ \text { alumni } \\
\text { associations / } \\
\text { professional } \\
\text { associations. }\end{array}$ & 1 & 1 & 1 & & 1 & & 1 & & & & \\
\hline & & $\begin{array}{l}\text { NI reflection in } \\
\text { university } \\
\text { strategy. }\end{array}$ & & & & & & & & & & & \\
\hline & \multirow{2}{*}{$\begin{array}{l}\text { The } \\
\text { manifestat } \\
\text { ion of } \\
\text { network } \\
\text { forms of } \\
\text { partnershi } \\
\text { p. }\end{array}$} & $\begin{array}{l}\text { University } \\
\text { participation in } \\
\text { university } \\
\text { consortiums/asso } \\
\text { ciations. }\end{array}$ & & & & 1 & & & & & & & \\
\hline & & $\begin{array}{l}\text { University } \\
\text { participation in }\end{array}$ & & & & & & & & & & & \\
\hline
\end{tabular}




\begin{tabular}{|c|c|c|c|c|c|c|c|c|c|c|c|c|c|}
\hline 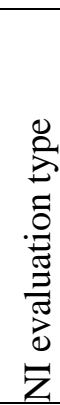 & $\begin{array}{l}\text { Evaluatio } \\
\text { n object }\end{array}$ & $\begin{array}{l}\text { Evaluation } \\
\text { ctiteria }\end{array}$ & 胥 & 疍 & $\stackrel{2}{\Omega}$ & $\stackrel{P}{\Omega}$ & 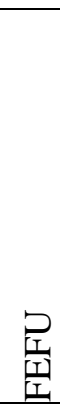 & $\stackrel{P}{D_{1}^{2}}$ & $\begin{array}{l}\mathrm{I} \\
\mathrm{Z}\end{array}$ & 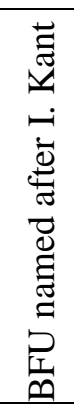 & $\begin{array}{l}\text { 志 } \\
\text { Z }\end{array}$ & 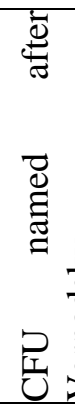 & 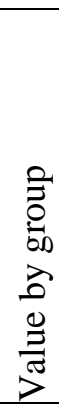 \\
\hline & & $\begin{array}{l}\text { online training } \\
\text { programs. }\end{array}$ & & & & & & & & & & & \\
\hline & Rating & $\max =6$ & 1 & 2 & 2 & 1 & 1 & 0 & 1 & 0 & 0 & 0 & 1 \\
\hline \multicolumn{3}{|c|}{$\begin{array}{l}\text { The total rating of the strategic } \\
\text { partnership development at a } \\
\text { university } \max =16\end{array}$} & 4 & 9 & 9 & 6 & 6 & 3 & 6 & 5 & 2 & 0 & 5 \\
\hline \multicolumn{3}{|c|}{$\begin{array}{l}\text { NI level in the Federal University } \\
\text { group }\end{array}$} & & & & & & & & & & & 5 \\
\hline
\end{tabular}

According to the results of the assessment, it can be noted that the level of strategic partnership readiness for networking among federal universities is also quite low.

\section{Discussion}

The assessment of the leading universities of the Russian Federation has revealed the general trends and features of strategic partnership development.

At the moment, Russian universities have a very low degree of information openness in strategic partnerships, which is inconsistent with the latest trends in education system development. Unlike Russian universities, foreign ones actively cover the results of joint activities with partners, especially in research and innovation activities.

It is possible to note a rather low level of Russian university readiness for networking, the development of strategic partnerships is traditionally aimed at educational activity provision, and at research and social activity to a lesser extent. Strategic partnership is considered more as a concomitant process for the functioning of universities, rather than one of its priority areas contributing to development.

It should be noted that the assessment proposed by the authors is not complete and requires certain modifications, which will be reflected in subsequent works.

\section{References}

Advison, L. (2005). Corporate longitude. Navigation in the knowledge-based economy: Translation from English. M.: INFRA-M, p. 247

Botnaryuk, M. V., \& Semerkova, L. N. (2011). Strategic Alliance or Network Interaction: the Problem of Choice. Social Sciences. Economy, 3, 19.

Bourdieu, P. (2005). Social space: fields and practices. St. Petersburg: Aletheia. p. 576

Castells, M., \& Blackwell, C. (1998). The information age: economy, society and culture. Volume 1. The rise of the network society. Environment and Planning B: Planning and Design, 25, 631-636.

Chekmarev, V. V. (2002). Economic space and its cellular network organization. Kostroma: KSU named after N.A. Nekrasov, p. 118. 
Gresko, A. A., Rakhmanov, M. S. \& Solodukhin, K. S. (2012). Relationship approach and stakeholder concept as the theoretical basis for the development of university strategic management methods. Modern problems of science and education. Electron. scientific magazine, 4. Recuperado de https://science-education.ru/ru/article/view?id=6846.

Isaev, S. N. \& Tikhomirova, N. V. (2011). The parameters of the network form of management in the production of educational services. New information technologies in education: mat. International scientific-practical Conf. Ekaterinburg: in 2 parts. Part 2. Ros. state prof.-ped. university - Ekaterinburg, 56-66.

Lazarev, G. I., Krivoshapova, S. V., Krivoshapov, V. G., \& Yarygin, A. N. (2018). University Integration Management Algorithm in the National Innovation System. The Journal of Social Sciences Research, 23, 310-315.

Mindeli, L. E., \& Pipiya, L. K. (2007). Conceptual aspects of formation of a knowledge-based economy. Studies on Russian Economic Development, 18(3), 314-327.

Nedoluzhko, O. V., Terentyeva, T. V., \& Shumik, E. G. (2019). The innovative potential as a factor in the dynamic development of entrepreneurship in the Russian Far East. Dilemas Contemporáneos: Educación, Política y Valore, 6(Special).

Palmer, A. J. (1996). Relationship marketing: a universal paradigm or management fad?. The learning organization, $3(3), 18-25$

Petruk, G. V. (2018). Internationalization of higher education of China as the factor of university competitiveness increase. Revista San Gregorio, 25, 179-185.

Ryuegg-Shturm, Y., \& Young, M. (2001). The value of the new network-like organizational and managerial forms for the dynamization of enterprises. The Problems of Theory and Practice Management, 6, 106-111.

Stryabkova, E. A. (2015). Cluster features as the forms of production territorial organization. Fundamental research. № 2-19. Recuperado de: https://fundamentalresearch.ru/ru/article/view?id=37941

Varkulevich, T. V., Shumik, E. G., \& Baturina, O. A. (2018). Strategic partnership of universities as a tool of territorial development dynamics: regional aspect. Revista ESPACIOS, $39(02)$.

Wenger, E. (1999). Communities of practice: Learning, meaning, and identity. Cambridge university press.

Zubarev, A. E., \& Ryabchenko, S. A. (2016). Modern experience and network partnership opportunities in the field of higher education. Bulletin of POSU, 2(41), 155-162. 